American Journal of Economics and Business Administration 1 (1) 34-40, 2009

ISSN 1945-5488

(C) 2009 Science Publications

\title{
Credit Market Development and Economic Growth
}

\author{
Athanasios Vazakidis and Antonios Adamopoulos \\ Department of Applied Informatics, \\ University of Macedonia Economic and Social Sciences, Greece
}

\begin{abstract}
Problem statement: This study investigated the relationship between credit market development and economic growth for Italy for the period 1965-2007 using a Vector Error Correction Model (VECM). Questions were raised whether economic growth spurs credit market development taking into account the negative effect of inflation rate on credit market development. This study aimed to investigate the short-run and the long-run relationship between bank lending, gross domestic product and inflation rate applying the Johansen cointegration analysis. Approach: For this objectives unit root tests were carried out according to Dickey-Fuller (1979) and Johansen cointegration analysis was applied to examine whether the variables are cointegrated of the same order taking into account the maximum eigenvalues and trace statistics tests. Finally, a vector error correction model was selected to investigate the long-run relationship between economic growth and credit market development. Results: A short-run increase of economic growth per $1 \%$ induces an increase of bank lending $0.4 \%$ in Italy, while an increase of inflation rate per $1 \%$ induces a relative decrease of bank lending per $0.5 \%$ in Italy. The estimated coefficient of error correction term is statistically significant and has a negative sign, which confirms that there is not any a problem in the long-run equilibrium between the examined variables. Conclusions: The empirical results indicated that economic growth has a positive effect on credit market development, while inflation rate has a negative effect. Bank development is determined by the size of bank lending directed to private sector at times of low inflation rates leading to higher economic growth rates.
\end{abstract}

Key words: Credit Market; Economic Growth; Vector Error Correction Model

\section{INTRODUCTION}

The relationship between economic growth and financial development has been an extensive subject of empirical research. The question is whether banks or stock markets proceed or follow economic growth unless there is a complementary relationship between them. The main objective of this paper was to investigate the relationship between economic growth and credit market development taking into account the effect of inflation rate on credit market development. Economic growth favours credit market development at times of low inflation rates. This paper tries to confirm this hypothesis examining a model of banking system in which bank lending is dependent on gross domestic product and consumer price index.

The literature on financial liberalization encourages free competition among banks as the way forward to achieve economic growth. However, it has largely overlooked the possibility that endogenous constraints in the credit market, such as imperfect information, could be a significant obstacle to efficient credit allocation even when assuming that banks are free from interest rate ceilings. Stiglitz ${ }^{[1]}$ were the first to consider the importance of banks in allocating credit efficiently, particularly to new and innovative investments.

A high risk premium would only encourage the riskier borrowers, as the higher the risk the higher the expected return from investment. The expected return of the borrowers is an increasing function of the riskiness of their projects. This fact would discourage less risky investments from taking place, although they could be more productive (selection effect). Safe borrowers, which deal with banks only, will be left with no other choice. At times of high interest rates, investors would favour investments with a high probability of default (incentive effect). Reducing opportunities to innovate will have a negative impact on economic growth in the long run.

King $^{[2]}$ use different measures of bank development for several countries and find that banking sector development can spur economic growth in the long run. Jayratne ${ }^{[3]}$ show that when individual states in USA relaxed interstate branching 
restrictions, bank lending quality increased significantly leading to higher growth. Government restrictions on banking systems through interest ceilings on deposits and high reserve requirements create a shortage of funds and reduce the efficiency of capital. Government ownership of banks is another form of intervention in financial systems which may have adverse impact on financial development. Privatizing government owned banks can enhance credit allocation and thereby increase quantity and quality of investment ${ }^{[4]}$. Levine $^{[5]}$ emphasizes the critical importance of the banking system in economic growth and highlight circumstances when banks can actively spur innovation and future growth by identifying and funding productive investments.

In a modern economy, banks and stock markets constitute a major part of the financial system. Although they may perform different roles in the process of economic development, their uniqueness is hardly emphasized within the framework of economic growth. The development of stock markets is necessary to achieve full efficiency of capital allocation if the government is to liberalize the financial system. While banks finance only wellestablished, safe borrowers, stock markets can finance risky, productive and innovative investment projects. As far as physical accumulation is concerned, both stock markets and banks provide sources of external financing for firms. For the purpose of resource allocation, they both create information to guide the allocation of resources. They differ only in the way the information is transmitted. Information in stock markets is contained in equity prices, while loan managers collect that in banks ${ }^{[6]}$. Dow $^{[7]}$ argued that if the main role of the stock markets to signal information for evaluation, financing and monitoring, banks may be equally effective at efficient resource allocation.

The effect of inflation on financial development is much more complicated. They hypothesize that a rise in inflation has a weak positive effect when initial rate of inflation is low and a negative effect at initially high inflation. If this hypothesis is true, then there is an inflation threshold in relationship between financial depth and inflation and this threshold can be regarded as an optimum rate of inflation with respect to financial development and therefore be a target for monetary authorities. Ball ${ }^{[9]}$ indicate that higher inflation necessarily raises inflation uncertainty. Higher inflation uncertainty increases the riskiness of all credits and therefore even previously 'high quality borrowers' get treated as the risky ones. To assure that credits are paid back banks may resort to more severe credit rationing.
Therefore, inflation may have different impact on financial depth depending on whether initial rate of inflation is high or low. A rise of initially low inflation may not lead to detrimental consequences for financial activity, whereas a rise in the rate of inflation that is initially high may substantially depress activity on financial markets and entail reduction in financial depth.

Khan $^{[8]}$ argue that besides inflation there might be several other factors affecting financial activity. Among them there are GDP per capita, the degree of openness and the share of public consumption in GDP as a measure of financial repression. Intuitively, the impact of these factors on financial development seems to be straightforward. A rise in GDP per capita and the degree of openness are likely to enlarge financial depth while a rise in financial repression and higher inflation seem to have an opposite result.

The model hypothesis predicts that economic growth facilitates credit market development taking into account the negative effect of inflation on credit market development.

This paper has two objectives:

- To apply a vector error correction model in order to examine the long-run and the shortrun relationship between the examined variables taking into Johansen cointegration method.

- To examine the effect of economic growth and inflation rate on credit market development

Initially the data and the specification of the multivariate VAR model are described. For this purpose stationarity test and Johansen co-integration analysis are examined taking into account the estimation of vector error correction model.

The empirical results are presented analytically and some discussion issues resulted from this empirical study are developed shortly, while the final conclusions are summarized relatively.

\section{MATERIALS AND METHODS}

Data and specification model: In this study the method of Vector Autoregressive Model (VAR) is adopted to estimate the effects of economic growth on credit market development through the effect of consumer price index. The use of this methodology predicts the cumulative effects taking into account the dynamic response among credit market development and the other examined variables ${ }^{[10,13]}$.

In order to test the long-run relationships, the following multivariate model is to be estimated: 
$\mathrm{BC}=\mathrm{f}(\mathrm{CPI}, \mathrm{GDP})$

Where:

$\mathrm{BC}=$ The domestic bank credits to private sector

$\mathrm{CPI}=$ The consumer price index

GDP $=$ The gross domestic product

Following the empirical study of ${ }^{[11]}$ the variable of economic growth (GDP) is measured by the rate of change of real GDP, while the credit market development is expressed by the domestic bank credits to private sector (BC) as a percentage of GDP.

This measure has a basic advantage from any other monetary aggregate as a proxy for credit market development. Although it excludes bank credits to the public sector, it represents more accurately the role of financial intermediaries in channeling funds to private market participants ${ }^{[12,14]}$.

The data that are used in this analysis are annual covering the period 1965-2007 for Italy, regarding 2000 as a base year. All time series data are expressed in their levels and are obtained from international financial statistics yearbook ${ }^{[15]}$ and estimated by using econometric computer software Eviews 5.0.

Unit root test: Time series analysis involving stochastic trends, Augmented Dickey-Fuller unit root tests are calculated for individual series to provide evidence as to whether the variables are integrated. This is followed by a multivariate cointegration analysis. Economic theory does not often provide guidance in determining which variables have stochastic trends and when such trends are common among variables. If these variables share a common stochastic trend, their first differences are stationary and the variables may be jointly cointegrated.

Augmented Dickey-Fuller (ADF) test involves the estimation one of the following three equations respectively:

$$
\begin{aligned}
& \Delta \mathrm{X}_{\mathrm{t}}=\beta \mathrm{X}_{\mathrm{t}-1}+\sum_{\mathrm{j}=1}^{\mathrm{p}} \delta_{\mathrm{j}} \Delta \mathrm{X}_{\mathrm{t}-\mathrm{j}}+\varepsilon_{\mathrm{t}} \\
& \Delta \mathrm{X}_{\mathrm{t}}=\alpha_{0}+\beta \mathrm{X}_{\mathrm{t}-1}+\sum_{\mathrm{j}=1}^{\mathrm{p}} \delta_{\mathrm{j}} \Delta \mathrm{X}_{\mathrm{t}-\mathrm{j}}+\varepsilon_{\mathrm{t}} \\
& \Delta \mathrm{X}_{\mathrm{t}}=\alpha_{0}+\alpha_{1} \mathrm{t}+\beta \mathrm{X}_{\mathrm{t}-1}+\sum_{\mathrm{j}=1}^{\mathrm{p}} \delta_{\mathrm{j}} \Delta \mathrm{X}_{\mathrm{t}-\mathrm{j}}+\varepsilon_{\mathrm{t}}
\end{aligned}
$$

\section{Seddighi ${ }^{[16]}$.}

The additional lagged terms are included to ensure that the errors are uncorrelated. The maximum lag length begins with 3 lags and proceeds down to the appropriate lag by examining the AIC and SC information criteria.

The null hypothesis is that the variable $\mathrm{X}_{\mathrm{t}}$ is a nonstationary series $\left(\mathrm{H}_{0}: \beta=0\right)$ and is rejected when $\beta$ is significantly negative $(\mathrm{Ha}: \beta<0)$. If the calculated ADF statistic is higher than McKinnon's critical values, then the null hypothesis $\left(\mathrm{H}_{0}\right)$ is not rejected and the series is non-stationary or not integrated of order zero $\mathrm{I}(0)$. Alternatively, rejection of the null hypothesis implies stationarity. Failure to reject the null hypothesis leads to conducting the test on the difference of the series, so further differencing is conducted until stationarity is reached and the null hypothesis is rejected ${ }^{[17,18]}$.

In order to find the proper structure of the ADF equations, in terms of the inclusion in the equations of an intercept $\left(\alpha_{0}\right)$ and a trend $(t)$ and in terms of how many extra augmented lagged terms to include in the ADF equations, for eliminating possible autocorrelation in the disturbances, the minimum values of ${ }^{[19]}$ information criterion (AIC) and $\mathrm{d}^{[20]}$ criterion (SC) based on the usual Lagrange Multiplier LM (1) test were employed.

The econometric software Eviews which is used to conduct the ADF tests, reports the simulated critical values based on response surfaces. The results of the Dickey-Fuller (DF) and Augmented' Dickey-Fuller (ADF) tests for each variable appear in Table 1.

If the time series (variables) are non-stationary in their levels, they can be integrated with integration of order 1, when their first differences are stationary.

Johansen cointegration analysis: Following the studies of Chang ${ }^{[28]}$, Chang and Caudill ${ }^{[27]}$, since it has been determined that the variables under examination are integrated of order 1 , then the cointegration test is performed. The testing hypothesis is the null of non-cointegration against the alternative that is the existence of cointegration using the Johansen maximum likelihood procedure ${ }^{[21,22]}$. Once a unit root has been confirmed for a data series, the question is whether there exists a long-run equilibrium relationship among variables. According to ${ }^{[23]}$, a set of variables, $Y_{t}$ is said to be cointegrated of order $(d, b)$-denoted CI $(d, b)$-if $Y_{t}$ is integrated of order $d$ and there exists a vector, $\beta$, such that $\beta^{\prime} Y_{t}$ is integrated of order (d-b).

Cointegration tests in this study are conducted using the method developed by ${ }^{[21,24]}$. The multivariate cointegration techniques developed by $^{[21,22,24]}$ using a maximum likelihood estimation procedure allows researchers to estimate simultaneously models involving two or more variables to circumvent the problems associated 
with the traditional regression methods used in previous studies on this issue. Therefore, the Johansen method applies the maximum likelihood procedure to determine the presence of cointegrated vectors in nonstationary time series.

Following the study of Chang and Caudill [27], Johansen $^{[24]} \mathrm{n}$ and Osterwald-Lenum ${ }^{[25]}$ propose two test statistics for testing the number of cointegrated vectors (or the rank of $\Pi$ ): The trace $\left(\lambda_{\text {trace }}\right)$ and the maximum eigenvalue $\left(\lambda_{\max }\right)$ statistics.

The Likelihood Ratio statistic (LR) for the trace test $\left(\lambda_{\text {trace }}\right)$ as suggested by ${ }^{[26]}$ is:

$$
\lambda_{\text {trace }}(\mathrm{r})=-\mathrm{T} \sum_{\mathrm{i}=\mathrm{r}+1}^{\mathrm{p}} \ln \left(1-\hat{\lambda}_{\mathrm{i}}\right)
$$

Where:

$$
\begin{aligned}
\hat{\lambda}_{\mathrm{i}}= & \text { The largest estimated value of ith } \\
& \begin{array}{l}
\text { characteristic root (eigenvalue) obtained from } \\
\text { the estimated } \Pi \text { matrix } \mathrm{r}=0,1,2, \ldots \mathrm{p}-1
\end{array} \\
\mathrm{~T}= & \text { The number of usable observations }
\end{aligned}
$$

The $\lambda_{\text {trace }}$ statistic tests the null hypothesis that the number of distinct characteristic roots is less than or equal to $\mathrm{r}$, (where $\mathrm{r}$ is 0,1 , or 2,) against the general alternative. In this statistic $\lambda_{\text {trace }}$ will be small when the values of the characteristic roots are closer to zero (and its value will be large in relation to the values of the characteristic roots which are further from zero)

Alternatively, the maximum eigenvalue $\left(\lambda_{\max }\right)$ statistic as suggested by Johansen is:

$$
\lambda_{\max }(\mathrm{r}, \mathrm{r}+1)=-\mathrm{T} \ln \left(1-\hat{\lambda}_{\mathrm{r}+1}\right)
$$

The $\lambda_{\max }$ statistic tests the null hypothesis that the number of $r$ cointegrated vectors is $r$ against the alternative of $(r+1)$ cointegrated vectors. Thus, the null hypothesis $r=0$ is tested against the alternative that $r=1, r=1$ against the alternative $r=2$ and so forth. If the estimated value of the characteristic root is close to zero, then the $\lambda_{\max }$ will be small.

It is well known that Johansen "s cointegration tests are very sensitive to the choice of lag length. Firstly, a VAR model is fitted to the time series data in order to find an appropriate lag structure. The Schwarz Criterion (SC) and the Likelihood Ratio (LR) test are used to select the number of lags required in the cointegration test. The Schwarz Criterion (SC) and the Likelihood Ratio (LR) test suggested that the value $p=3$ is the appropriate specification for the order of VAR model for Italy. Table 2 shows the results from the Johansen cointegration test.
Vector Error Correction Model: According to the study of Chang and Caudill ${ }^{[27]}$, since the variables included in the VAR model are found to be cointegrated, the next step is to specify and estimate a Vector Error Correction Model (VECM) including the error correction term to investigate dynamic behavior of the model. Once the equilibrium conditions are imposed, the VEC model describes how the examined model is adjusting in each time period towards its long-run equilibrium state.

Since the variables are supposed to be cointegrated, then in the short run, deviations from this long-run equilibrium will feed back on the changes in the dependent variables in order to force their movements towards the long-run equilibrium state. Hence, the cointegrated vectors from which the error correction terms are derived are each indicating an independent direction where a stable meaningful long-run equilibrium state exists.

The VEC specification forces the long-run behaviour of the endogenous variables to converge to their cointegrated relationships, while accommodates short-run dynamics. The dynamic specification of the model allows the deletion of the insignificant variables, while the error correction term is retained. The size of the error correction term indicates the speed of adjustment of any disequilibrium towards a long-run equilibrium state ${ }^{[23]}$. The error-correction model with the computed $\mathrm{t}$-values of the regression coefficients in parentheses is reported in Table 3.

The final form of the Error-Correction Model (ECM) was selected according to the approach suggested by Hendry ${ }^{[26]}$. The general form of the Vector Error Correction Model (VECM) is the following one:

$\Delta \mathrm{BC}_{\mathrm{t}}=\beta_{0}+\sum_{\mathrm{i}}^{\mathrm{n}} \beta_{1} \Delta \mathrm{CPI}_{\mathrm{t}-\mathrm{i}}+\sum_{\mathrm{i}}^{\mathrm{n}} \beta_{2} \Delta \mathrm{GDP}_{\mathrm{t}-\mathrm{i}}+\sum_{\mathrm{i}}^{\mathrm{n}} \beta_{3} \Delta \mathrm{BC}_{\mathrm{t}-\mathrm{i}}+\lambda \mathrm{EC}_{\mathrm{t}-\mathrm{i}}+\varepsilon_{\mathrm{t}}(7)$

Where:

$\Delta=$ The first difference operator

$\mathrm{EC}_{\mathrm{t}-1}=$ The error correction term lagged one period

$\lambda=$ The short-run coefficient of the error correction term $(-1<\lambda<0)$

$\varepsilon_{\mathrm{t}} \quad=$ The white noise term

\section{RESULTS}

The observed t-statistics in the Table 1 fail to reject the null hypothesis of the presence of a unit root for all variables in their levels confirming that they are non-stationary at $1 \%$ and $5 \%$ levels of significance. However, the results of the DF and ADF tests show that the null hypothesis of the 
presence of a unit root is rejected for all variables when they are transformed into their first differences.

Therefore, all series that are used for the estimation of $\mathrm{ADF}$ equations are non-stationary in their levels, but stationary and integrated of order one $\mathrm{I}(1)$, in their first differences. Moreover, the LM(1) test shows that there is no correlation in the disturbance terms for all variables in their first differences. These variables can be cointegrated as well, if there are one or more linear combinations among the variables that are stationary.

The results that appear in Table 2 suggest that the number of statistically significant cointegration vectors for Italy is equal to 1 and is the following:

$\mathrm{BC}=1.12-4.81 \mathrm{CPI}+4.95 \mathrm{GDP}$

The cointegration vector of the model of Italy presented in Table 2 has $\operatorname{rank} r<n(n=3)$. The process of estimating the rank $r$ is related with the assessment of eigenvalues, which are the following for Italy: $\hat{\lambda}_{1}=0.5047, \hat{\lambda}_{2}=0.2515$, and $\hat{\lambda}_{3}=0.0890$.

Critical values for the trace statistic defined by Eq. 5 are 34.91 and 41.07 for Ho: $r=0$ and 19.96 and 24.60 for Ho: $r \leq 1,9.24$ and 12.97 for Ho: $r \leq 2$ at the significance level 5 and $10 \%$ respectively as reported by ${ }^{[25]}$, while critical values for the maximum eigenvalue test statistic defined by Eq. 6 are 22.00 and 26.81 for Ho: $r=0,15.67$ and 20.20 for Ho: $r \leq 1,9.24$ and 12.97 for Ho: $r \leq 2$. The errorcorrection model with the computed t-values of the regression coefficients in parentheses is reported in Table 3. The dynamic specification of the model allows the deletion of the insignificant variables, while the error correction term is retained. From the results of Table 3 we can see that a short-run increase of economic growth per $1 \%$ induces an increase of bank lending $0.4 \%$ in Italy, while an increase of inflation rate per $1 \%$ induces a relative decrease of bank lending per $0.5 \%$ in Italy. The estimated coefficient of $\mathrm{EC}_{\mathrm{t}-1}$ is statistically significant and has a negative sign, which confirms that there is not any a problem in the long-run equilibrium relation between the independent and dependent variables in 5\% level of significance, but its relatively value $(-0.07)$ for Italy shows a satisfactory rate of convergence to the equilibrium state per period.

Table 1: DF/ADF unit root tests

\begin{tabular}{|c|c|c|c|c|c|c|c|c|c|c|}
\hline \multicolumn{6}{|c|}{ In levels } & \multicolumn{5}{|c|}{ In first differences } \\
\hline & \multicolumn{5}{|c|}{ cr_val $(\%)$} & \multicolumn{5}{|c|}{ cr_val (\%) } \\
\hline Variables & $\underset{\text { eq_f }}{\operatorname{lag}_{f}}$ & $\begin{array}{l}\text { adf_test } \\
\text { stat }\end{array}$ & $\begin{array}{l}1 \\
5 \\
10\end{array}$ & $\begin{array}{l}\mathrm{AIC} \\
\mathrm{SBC}\end{array}$ & $\begin{array}{l}\text { LM } \\
\text { [prob] }\end{array}$ & $\operatorname{lag}_{\text {eq_f }}$ & $\underset{\text { stat }}{\text { adf_test }}$ & $\begin{array}{l}1 \\
5 \\
10\end{array}$ & $\begin{array}{l}\mathrm{AIC} \\
\mathrm{SBC}\end{array}$ & $\begin{array}{l}\mathrm{LM} \\
\text { [prob] }\end{array}$ \\
\hline$\overline{\mathrm{BC}}$ & $\begin{array}{l}\rho=0 \\
(1)\end{array}$ & $\begin{array}{c}1.3234 \\
{[0.9509]}\end{array}$ & $\begin{array}{l}-2.6211 \\
-1.9488 \\
-1.6119\end{array}$ & $\begin{array}{l}-2.5474 \\
-2.5060\end{array}$ & $\begin{array}{c}0.1757 \\
{[0.8394]}\end{array}$ & $\begin{array}{l}\rho=0 \\
(1)\end{array}$ & $\begin{array}{l}-5.9519 \\
{[0.0000]}\end{array}$ & $\begin{array}{l}-2.6225 \\
-1.9490 \\
-1.6118\end{array}$ & $\begin{array}{l}-2.5420 \\
-2.5003\end{array}$ & $\begin{array}{r}0.2281 \\
{[0.7971]}\end{array}$ \\
\hline CPI & $\begin{array}{l}\rho=0 \\
(3)\end{array}$ & $\begin{array}{l}-3.0518 \\
{[0.1313]}\end{array}$ & $\begin{array}{l}-4.1985 \\
-3.5236\end{array}$ & $\begin{array}{l}-7.3591 \\
-7.1919\end{array}$ & $\begin{array}{c}0.5242 \\
{[0.5965]}\end{array}$ & $\begin{array}{l}\rho=0 \\
(1)\end{array}$ & $\begin{array}{l}-5.2087 \\
{[0.0000]}\end{array}$ & $\begin{array}{l}-2.6240 \\
-1.9493\end{array}$ & $\begin{array}{l}-7.1870 \\
-7.1448\end{array}$ & $\begin{array}{r}0.1557 \\
{[0.8563]}\end{array}$ \\
\hline GDP & $\begin{array}{l}\rho=0 \\
\text { (3) }\end{array}$ & $\begin{array}{l}-2.2854 \\
{[0.4323]}\end{array}$ & $\begin{array}{l}-3.1929 \\
-4.1923 \\
-3.5207\end{array}$ & $\begin{array}{l}-4.3066 \\
-4.1825\end{array}$ & $\begin{array}{c}1.7113 \\
{[0.1946]}\end{array}$ & $\begin{array}{l}\rho=0 \\
(2)\end{array}$ & $\begin{array}{l}-4.4533 \\
{[0.0009]}\end{array}$ & $\begin{array}{l}-1.6117 \\
-3.6009 \\
-2.9350\end{array}$ & $\begin{array}{l}-4.2142 \\
-4.1306\end{array}$ & $\begin{array}{r}0.8334 \\
{[0.4425]}\end{array}$ \\
\hline & & & -3.1912 & & & & & -2.6058 & & \\
\hline
\end{tabular}

Eq_f: Equation form; Cr_val: Critical values; AIC: Akaike criterion; SBC: Schwarz Bayesian Criterion; LM: Langrage Multiplier test

Table 2: Johansen and juselious cointegration tests (BC, CPI,GDP)

\begin{tabular}{lcrcr}
\hline \multicolumn{4}{c}{ Country (Italy) } \\
\hline \multicolumn{4}{c}{ Johansen test statistics } \\
& \multicolumn{3}{c}{ Cr_v (\%) } & Cr_v (\%) \\
Testing & \multicolumn{3}{c}{5} & 5 \\
hypothesis & $\lambda_{\text {trace }}$ & 1 & $\lambda_{\max }$ & 1 \\
\hline $\mathrm{H}_{0}: \mathrm{r}=0$ and $\mathrm{r}=1$ & 43.42 & 34.91 & 28.10 & 22.00 \\
& & 41.07 & & 26.81 \\
$\mathrm{H}_{0}: \mathrm{r} \leq 1$ and $\mathrm{r}=2$ & 15.31 & 19.96 & 11.58 & 15.67 \\
& & 24.60 & & 20.20 \\
$\mathrm{H}_{0}: \mathrm{r} \leq 2$ and $\mathrm{r}=3$ & 3.730 & 9.24 & 3.73 & 9.24 \\
& & 12.97 & & 12.97 \\
Cointegrated vectors & 1(both 5 and 1\%) & 1(both 5 and 1\%) \\
\hline
\end{tabular}

Notes: Cr_v: Critical values

Table 3: Vector error correction model

\begin{tabular}{lc}
\hline Independent variable & Estimated coefficients \\
\hline Constant & $-0.1492[0.095]$ \\
$\Delta \mathrm{CPI}_{\mathrm{t}-\mathrm{i}}$ & $-0.5611[0.043]$ \\
$\Delta \mathrm{GDP}_{\mathrm{t}}$ & $0.4190[0.254]$ \\
$\mathrm{ECT}_{\mathrm{t}-1}$ & $-0.0749[0.049]$ \\
$\mathrm{R}^{2}$ & 0.1315 \\
$\mathrm{DW}$ & 2.3121 \\
Serial correlation & $2.8058[0.094]$ \\
Functional Form & $4.4831[0.034]$ \\
Normality & $0.6415[0.726]$ \\
Heteroscedasticity & $2.2389[0.135]$ \\
\hline
\end{tabular}


[ ]: I denote the probability levels; $\Delta$ : Denotes the first differences of the variables; $R^{2}$ : Coefficient of multiple determinations adjusted for the degrees of freedom (df); DW: Durbin-watson statistic

\section{DISCUSSION}

The model of banking system is mainly characterized by the effect of interest rates, investments and the circulation of money. However, bank development is determined by the size of bank lending directed to private sector at times of low inflation rates leading to higher economic growth rates. Businesses make new investments to innovative products through bank lending in more developed countries.

Interest rate is not included in the estimated model of banking system due to the insignificance of estimation results. The significance of the empirical results is dependent on the variables under estimation.

Less empirical studies have concentrated on examining the reverse relationship between economic growth and credit market development taking into account the effect of inflation rate. Most empirical studies examine the relationship between economic growth and stock market development.

The results of this paper are agreed with the studies of $\operatorname{Khan}^{[8]}$ and Levine ${ }^{[5]}$. However, more interest should be focused on the comparative analysis of empirical results for the rest of European Union members-states in future research.

\section{CONCLUSION}

This study employs with the relationship between credit market development and economic growth for Italy, using annually data for the period 1965-2007. The empirical analysis suggested that the variables that determine credit market present a unit root. Once a cointegrated relationship among relevant economic variables is established, the next issue is how these variables adjust in response to a random shock. This is an issue of the short-run disequilibrium dynamics. The short run dynamics of the model is studied by analyzing how each variable in a cointegrated system responds or corrects itself to the residual or error from the cointegrating vector. This justifies the use of the term error correction mechanism.

The Error Correction (EC) term, picks up the speed of adjustment of each variable in response to a deviation from the steady state equilibrium. The dynamic specification of the model suggests deletion of the insignificant variables while the error correction term is retained. The VEC specification forces the long-run behaviour of the endogenous variables to converge to their cointegrating relationships, while accommodates the short-run dynamics.

A short-run increase of economic growth per $1 \%$ induces an increase of bank lending $0.4 \%$ in Italy, while an increase of inflation rate per $1 \%$ induces a relative decrease of bank lending per $0.5 \%$ in Italy.

Therefore, it can be inferred that economic growth has a direct positive effect on credit market development, taking into account the negative effect of inflation rate on credit market development.

Economic growth spurs credit market development at times of low inflation rates. This fact will encourage more risky investments from taking place, while safe borrowers who deal only with banks will become more effective. Increasing opportunities to innovative products will favour new investments from domestic and foreign investors leading to higher economic growth in the long-run period.

The issue of causal relationship between credit market development and economic growth is regarded as an important subject under estimation in future empirical studies.

\section{REFERENCES}

1. Stiglitz, J. and A. Weiss, 1981. Credit rationing in markets with imperfect information. Am. Econ. Rev., 71: 383-410. http://ideas.repec.org/a/aea/aecrev/ v71y1981i3p393-410.html

2. King, R. and R. Levine, 1993. Finance, entrepreneurship and growth: Theory and evidence. J. Monetary Econ., 32: 513-542. http://ideas.repec.org /a/eee/moneco/v32y1993i3p513-542.html

3. Jayratne, J. and P. Strahan, 1996. The finance-growth nexus: Evidence from bank branch deregulation. Q. J. Econ., 111: 639-670. http://ideas.repec.org/a/tpr/ qjecon/v111y1996i3p639-70.html

4. Demetriades, P. and S. Andrianova, 2004. Finance and Growth: What We Know and What We Need to Know. In: Financial Development and Growth: Explaining the Links, Goodhart, C.A. (Ed.). Palgrave Macmillan Great Britain, ISBN: 9781403920669. pp: 38-65.

http://www.le.ac.uk/economics/research/RePEc/lec/le econ/dp03-15.pdf

5. Levine, R., 2002. Bank based or market-based financial systems: Which is better? J Fin Intermediation, 11: 398-428.

6. Caporale, G., P. Howells and A. Soliman, 2005. Endogenous growth models and stock market development: Evidence from four countries. Rev. 
Develop. Econ., 9: 166-176. http://papers.ssrn.com /sol3/papers.cfm?abstract_id=712949

7. Dow, J. and G. Gorton, 1995. Stock market efficiency and economic efficiency: Is there a connection. J. Finance Am. Finance Assoc., 52: 1087-1129. http://ideas.repec.org/p/nbr/nberwo/5233 .html

8. Khan, M. Senhadji and B. Smith, 2001. Inflation and financial depth. IMF Working Paper WP/01/44.http://www.imf.org/external/pubs/cat/longr es.cfm?sk=40530

9. Ball, L. and G. Mankiw, 1995. Relative-price changes as aggregate supply shocks. Q. J. Econ., 110: 161-193.http://ideas.repec.org/a/tpr/qjecon/v110y 1995i1p161-93.html

10. Pereira, A. and Z. Xu, 2000. Export growth and domestic performance. Rev. Int. Econ., 8: 60-73. DOI: 10.1111/1467-9396.00205

11. King, R. and R. Levine, 1993. Finance and growth: Schumpeter might be right. Q. J. Econ., 108: 717737.http://ideas.repec.org/a/tpr/qjecon/v108y1993i3p 717-37.html

12. Levine, R., N. Loyaza and T. Beck, 2000. Financial intermediation and growth: Causality and causes. J. Monetary Econ., 46: 31-77. http://ideas.repec.org /a/eee/moneco/v46y2000i1p31-77.html

13. Katos, A. G. Pekos, E. Katsouli, and C. Batzios, 1996. Saving-Investment Equilibrium in the European Union: An Economic Policy Exercise, Riv. Int. de Sci. Econ. e Com., 43: 81-107

14. Vazakides, A., 2006. Testing simple versus dimson market models: The case of Athens stock exchange. Int. Res. J. Finance Econ., 2: 26-34. http://www.eurojournals.com/IRJFE\%202\%203\%20 Vazakides.pdf

15. International Monetary Fund, (IMF), 2006. International Financial Statistics Yearbook. Various Years, Washington DC. ISBN: 1589065778, pp: 205.

16. Seddighi, H., K. Lawler, and A. Katos, (2000) Econometrics: A Practical Approach. 1st ed. Routledge, London, ISBN: 0415156440. pp: 397.

17. Dickey, D. and W. Fuller, 1979. Distributions of the estimators for autoregressive time series with a unit root. J. Am. Stat. Assoc., 74: 427-431. http://www.citeulike.org/user/ChristianRauh/article/2 362437

18. Katos, A. 2004. Econometrics, Theory and Practice, 1st ed. Zygos, Thessaloniki, ISBN: 9789608065444 pp: 1200.

19. Akaike, H., 1973. information theory and an extension of the maximum likelihood principle, Proceeding of the 2nd International Symposium on Information Theory, (ISIT'73), Akademiai Kiado, Budapest, pp: 267-281. http://bibnetwiki.org/wiki/
Information_theory_and_an_extension_of_the_maxi mum_likelihood_principle

20. Schwarz, R., 1978. Estimating the dimension of a model. Ann. Stat., 6: 461-464. http://projecteuclid.org/DPubS?service=UI\&version= $1.0 \&$ verb=Display\&handle=euclid.aos $/ 1176344136$

21. Johansen, S. and K. Juselious, 1990. Maximum likelihood estimation and inference on cointegration with applications to the demand for the money. Oxford Bull. Econ. Stat., 52: 169-210. http://ideas.repec.org/a/bla/obuest/v52y1990i2p169210.html

22. Johansen, S. and K. Juselius, 1992. Testing structural hypotheses in a multivariate cointegration analysis at the purchasing power parity and the uncovered interest parity for the UK. J. Econ., 53: 211-244. http://ideas.repec.org/p/kud/kuiedp/9005.html

23. Engle, R. and C. Granger, 1987. Cointegration and error correction: Representation, estimation and testing. Econometrica, 55: 251-276. http://ideas.repec.org/a/ecm/emetrp/v55y1987i2p25176.html

24. Johansen, S., 1988. Statistical analysis of cointegration vectors. J. Econ. Dyn. Control, 12: 231254.http://ideas.repec.org/a/eee/dyncon/v12y1988i23 p231-254.html

25. Osterwald-Lenum, M., 1992. A note with quantiles of the asymptotic distribution of the maximum likelihood cointegration rank test statistics. Oxford Bull. Econ. Stat., 54: 461-472. http://ideas.repec.org/a/bla/obuest/54y1992i3p46172.html

26. Maddala, G., 1992. Introduction to Econometrics. 2nd ed. Macmillan, New York, ISBN: 0023745452, pp: 663.

27 Chang, T., and Caudill, S., (2005) Financial development and economic growth: the case of Taiwan, Ap. Econ., 37: 1329-1335 http://ideas.repec.org/a/taf/applec/v37y2005i12p1329 $-1335 . h t m l$

28. Chang, T., (2002) An econometric test of Wagner's law for six countries based on cointegration and error-correction modelling techniques, Applied Economics, 34(9), 1157-1169 http://ideas.repec .org /a/taf/applec/v34y 2002i9p1157-69.html 